\title{
PENGEMBANGAN ALAT BANTU KOMUNIKASI PENDERITA PASCASTROKE MENGGUNAKAN FLEX SENSOR DAN ACCELEROMETER
}

\author{
Agung W. Setiawan', Lavita N. Rizalputri², Ahmad H. Thias ${ }^{3}$ \\ Sekolah Teknik Elektro dan Informatika, Institut Teknologi Bandung 1,2,3 \\ Email: ${ }^{1}$ awsetiawan@ @stei.itb.ac.id, ${ }^{2}$ Lavita.nuraviana@gmail.com, ${ }^{3}$ ahmadhabbie@ gmail.com
}

(Naskah masuk: 19 November 2018, diterima untuk diterbitkan: 18 Desember 2018)

\begin{abstract}
Abstrak
Pada tahun 2013, prevelansi penderita stroke di Indonesia sebesar 12,1\% serta merupakan penyebab kematian kedua dan penyebab disabilitas ketiga di dunia. Di Indonesia, angka kontribusi proporsional disabilityadjusted life-years (DALYs) dari stroke sekitar 9,7\% dan merupakan penyebab disabilitas nomor satu. Penderita yang mengalami disabilitas akan kesulitan melakukan aktivitas sehari-hari, terutama berkomunikasi. Oleh karena itu perlu dikembangkan alat bantu komunikasi yang dapat membantu penderita pascastroke berkomunikasi seharihari dengan memanfaatkan gerakan telapak tangan. Pada penelitian ini digunakan empat buah flex sensor yang diletakkan pada jari telunjuk, tengah, manis, dan kelingking serta satu sensor 3-axis gyroscope MPU6050. Alat bantu komunikasi untuk penderita pascastroke ini telah berfungsi untuk mendeteksi tujuh gerakan dasar, yaitu: "Ya", "Tidak", "Saya mau pergi kesana", "Jam berapa sekarang?", "Saya mau makan", "Saya mau minum”, dan "Halo!". Ketujuh kata atau kalimat tersebut juga ditampilkan di sebuah display. Pendeteksian ketujuh gerakan ini diperoleh dari tekukan empat jari yang dideteksi menggunakan flex sensor dan posisi tangan di arah 3 sumbu (x, $\mathrm{y}$, dan z) menggunakan gyroscope yang diletakkan pada sebuah sarung tangan. Alat ini diharapkan dapat menjadi awal dalam pengembangan alat bantu komunikasi untuk penderita.
\end{abstract}

Kata kunci: alat bantu komunikasi, penderita pascastroke, deteksi gerakan tangan, komunikasi sehari-hari.

\section{DEVELOPMENT OF COMMUNICATION ASSISTIVE DEVICE USING FLEX SENSOR AND ACCELEROMETER FOR POST-STROKE PATIENT}

\begin{abstract}
In 2013, prevalence of stroke in Indonesia is $12.1 \%$ and the second leading cause of deaths and the third most common cause of disability in the world. In Indonesia, disability-adjusted life-years (DALYs) proportional contribution of stroke is around $9.7 \%$ and the first leading cause of disability. Patients with disabilities will have difficulty for performing daily life activities, especially communicating with other people. Therefore, it is necessary to develop communication assistive device that can help post-stroke patients to communicate using their palm. Four flex sensors mounted on the index, middle, ring, and pinky fingers; and one 3-axis gyroscope MPU6050 sensor. This communication asisstive device has fully function to detect seven basic movement for daily life communication, that is: "Yes", "No", "I want to go there", "What time is it?", "I want to eat", "I want to drink" and "Hello!". The seven words / sentences also appear on the viewer screen. The detection of these seven motions is obtained from the four flex sensors and the position of the hand in the 3-axes (x, y, and z) direction from gyroscope that is placed on a glove. This research is a preliminary research in the area of assistive device technology for post-stroke patients.
\end{abstract}

Keywords: communication assistive device, post-stroke patient, palm gesture, daily communication.

\section{PENDAHULUAN}

Berdasarkan data dari Riset Kesehatan Dasar (Riskesdas) yang dilakukan oleh Kementerian Kesehatan Republik Indonesia pada tahun 2013, prevelansi penderita stroke di Indonesia sebesar 12,1 $\%$. Hal ini mengalami peningkatan sebesar 3,8\% dibandingkan dengan data Riskesdas tahun 2007 (8,3 $\%)$. Pada tahun 2013, stroke merupakan penyebab kematian nomor dua dan merupakan penyebab disabilitas nomor tiga di dunia. Di Indonesia, stroke merupakan penyebab disabilitas nomor satu dengan angka kontribusi proporsional Disability-Adjusted Life-Years (DALYs) dari stroke sekitar 9,7\% dari semua penyebab, dan ini merupakan salah satu yang tertinggi di dunia (Feigin, dkk., 2017). DALYs adalah salah satu cara ukuran terbaik untuk mengukur stroke burden yang digunakan oleh World Health Organization (WHO). 
Pasien pascastroke yang mengalami disabilitas akan kesulitan melakukan aktivitas sehari-hari, terutama berkomunikasi dengan orang lain. Hal ini mengakibatkan penderita pascastroke mengalami penurunan kualitas hidup. Supaya mampu melakukan komunikasi, penderita pascastroke perlu melakukan terapi, namun proses ini memerlukan waktu. Oleh karena itu, dalam penelitian ini dikembangkan alat bantu komunikasi untuk penderita pascastroke. Tujuan penelitian adalah untuk membantu penderita pascastroke yang kesulitan berkomunikasi, terutama untuk komunikasi sehari-hari dengan memanfaatkan gerakan jari dan telapak tangan. Diharapkan, dengan dikembangkannya alat bantu komunikasi ini, terjadi peningkatan kualitas hidup penderita pascastroke yang mengalami disabilitas.

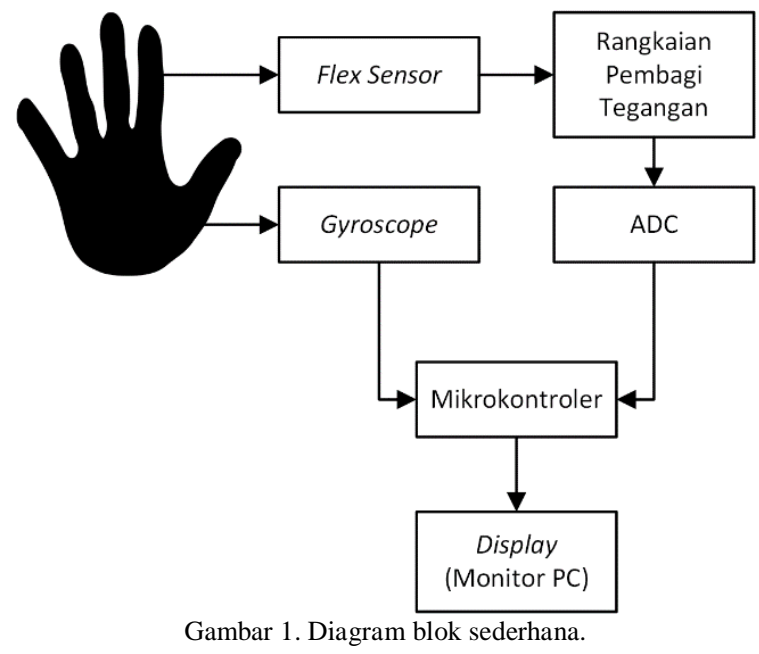

Alat bantu komunikasi untuk penderita pascastroke ini memanfaatkan gerakan jari dan telapak tangan. Gerakan-gerakan ini akan dideteksi oleh empat flex sensor dan sebuah gyroscope yang diletakkan pada sebuah sarung tangan. Pada saat penderita pascastroke melakukan sign language, maka terjadi peregangan dan pelipatan sendi jari. Flex sensor yang terpasang pada jari-jari tangan akan memberikan informasi peregangan dan/atau pelipatan sendi jari tangan yang berbeda. Selanjutnya, informasi ini akan diolah atau diterjemahkan oleh komputer menjadi kata atau kalimat yang dapat dimengerti oleh orang lain. Diagram blok sederhana dari alat bantu komunikasi penderita pascastroke ini dapat dilihat pada Gambar 1.

\section{METODOLOGI}

Proses pembuatan alat bantu komunikasi ini dapat dilihat pada diagram alir pada Gambar 2. Tahap pertama penelitian adalah mencari permasalahan yang masih belum terselesaikan, pada penelitian ini dipilih alat bantu komunikasi untuk penyandang disabilitas. Tahap selanjutnya adalah melakukan kajian pustaka dan studi mengenai produk atau penelitian yang berkaitan dengan topik penelitian yang akan dilakukan. Dari beberapa kasus disabilitas, dipilih disabilitas yang dialami oleh para penderita pascastroke yang sudah mengalami kondisi afasia atau disartria. Penderita pascastroke ini masih memiliki fungsi kognitif yang normal, akan tetapi memiliki kesulitan untuk berkomunikasi dengan normal. Langkah selanjutnya adalah mencari cara bagaimana penderita pascastroke ini supaya mampu berkomunikasi kembali. Salah satu cara yang diusulkan dan dikembangkan dalam penelitian ini adalah dengan merancang alat bantu komunikasi menggunakan sarung tangan. Fungsi dari alat ini adalah menerjemahkan gerakan tangan menjadi kata atau kalimat sehari-hari yang dibutuhkan penderita.

Tahap selanjutnya adalah melakukan pemilihan komponen dan modul elektronika yang akan digunakan. Semua komponen dan modul elektronika ini perlu diketahui spesifikasinya dengan jelas, terdapat datasheet. Hal ini penting supaya tidak terjadi kesalahan dalam proses perancangan alat. Disamping itu, yang juga perlu dilakukan adalah melakukan kalibrasi pada sensor-sensor yang akan digunakan. Hal ini penting dilakukan supaya karakteristik sensor telah sesuai dengan datasheet. Apabila belum, maka perlu dilakukan penyesuaian.

Setelah itu masuk ke tahap pembuatan alat yang dilakukan secara modular. Hal ini dilakukan untuk mempermudah implementasi dan troubleshooting apabila terdapat kesalahan dalam realisasi alat. Langkah selanjutnya adalah pengambilan data yang digunakan untuk membuat look-up table. Tahap terakhir adalah melakukan uji coba dan analisis.

\section{POSISI PENELITIAN: ALAT}

Pada saat ini, terdapat beberapa alat bantu komunikasi yang telah dikembangkan untuk para penderita pascastroke. Salah satu contohnya adalah alat bantu komunikasi menggunakan keyboard yang digunakan untuk menuliskan kata atau kalimat yang diinginkan penderita pascastroke. Komputer akan menerjemahkan kalimat yang sudah diketik tersebut menjadi suara dengan menggunakan modul text-tospeech. Salah satu kelebihan alat ini adalah penderita pascastroke dapat menuliskan beberapa kata atau kalimat yang ingin disampaikan. Akan tetapi, metode ini memiliki keterbatasan atau kekurangan, yaitu seringkali para pengguna mengalami kesulitan untuk mengetik kata atau kalimat yang diinginkan. Karena memerlukan waktu yang relatif lama untuk mengetik. Padahal penderita pascastroke hanya ingin menyampaikan hal-hal yang sifatnya rutin dan berulang. Sehingga alat ini dianggap kurang efektif.

Selain alat bantu berbasis perangkat keras, juga terdapat beberapa aplikasi (berbasis perangkat lunak) yang digunakan untuk menunjang dan membantu penderita pascastroke supaya dapat berkomunikasi, terutama berbicara. Namun, fungsi utama dari aplikasi ini adalah digunakan sebagai alat bantu terapi dan tidak digunakan sebagai alat bantu komunikasi.

Pada penelitian yang lain, telah dikembangkan alat bantu komunikasi menggunakan sarung tangan 
yang menerjemahkan gerakan bahasa isyarat untuk para tuna wicara. Alat ini menggunakan biosinyal yang berasal dari aktivitas listrik otot, sinyal elektromiografi (EMG). Sinyal EMG ini akan diolah dengan menggunakan suatu pengolah sinyal yang digunakan untuk menerjemahkannya menjadi kata atau kalimat yang sesuai dengan kamus bahasa isyarat. Untuk penderita pascastroke, alat ini memiliki kekurangan, yaitu tidak semua penderita pascastroke dapat dengan cepat mengenali atau memahami bahasa isyarat ini. Karena penderita pascastroke perlu berlatih membaca gerakan bahasa isyarat yang cukup kompleks.

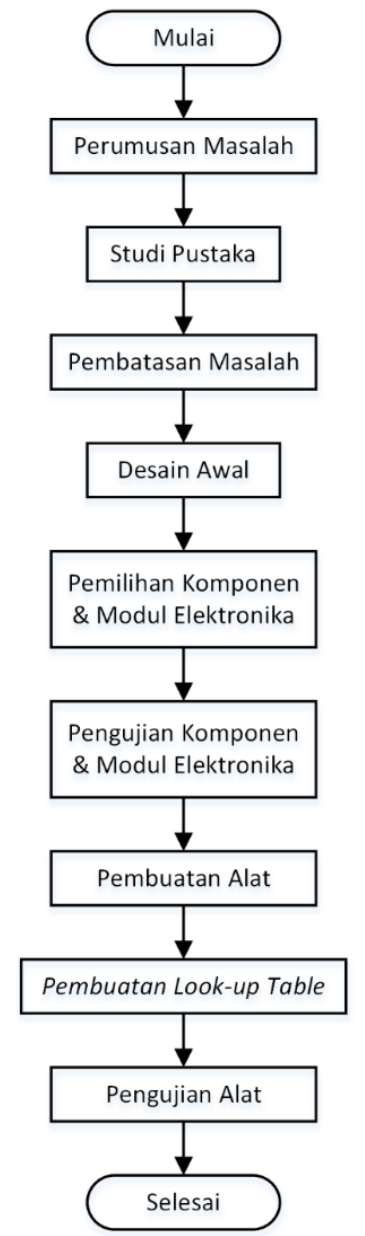

Gambar 2. Diagram alir penelitian.

Berdasarkan studi yang telah dilakukan di atas, pada penelitian ini dipilih alat bantu komunikasi menggunakan sarung tangan yang dirancang khusus untuk penderita pascastroke. Prinsip kerja alat ini hampir sama dengan sarung tangan penerjemah untuk tuna wicara. Pada penelitian ini tidak menggunakan EMG, tetapi digunakan flex sensor dan gyroscope. Selain itu, gerakannya dibuat lebih sederhana dan dirancang khusus untuk menampilkan beberapa kata atau kalimat sederhana yang sering digunakan seharihari. Sehingga penderita pascastroke dapat dengan mudah dan cepat mengomunikasikan hal-hal diinginkan.

\section{SPESIFIKASI SISTEM}

Pada penelitian ini, digunakan empat buah flex sensor yang dipasang pada jari telunjuk, tengah, manis, dan kelingking. Pemilihan empat buah flex sensor dan pemasangan di keempat jari ini didasarkan pada kemudahan sign language yang dapat dilakukan oleh penderita stroke. Pada penelitian ini, ibu jari tidak dipasang flex sensor supaya lebih nyaman, dapat bebas bergerak, dan pengolahan informasi dari sensor tidak terlalu kompleks. Sign language yang digunakan dalam penelitian ini diadaptasi dari basis American Sign Language (ASL). Cara kerja dari flex sensor pada alat ini adalah apabila terjadi peregangan dan/atau pelipatan sendi jari, maka terjadi perubahan resistensi flex sensor. Supaya dapat diproses oleh modul Analog-to-Digital Converter (ADC), maka diperlukan rangkaian pengkondisi sinyal sederhana, berupa rangkaian pembagi tegangan. Dengan adanya rangkaian ini, perubahan resistansi flex sensor diubah menjadi tegangan. Tegangan ini yang akan menjadi masukan ADC. Spesifikasi flex sensor yang digunakan dalam penelitian ini adalah berbahan carbon resistive element yang memiliki resistansi 25 $\mathrm{k} \Omega$ ketika lurus $\left(0^{\circ}\right)$ dan $90 \mathrm{k} \Omega$ ketika dibengkokkan sebesar $90^{\circ}$.

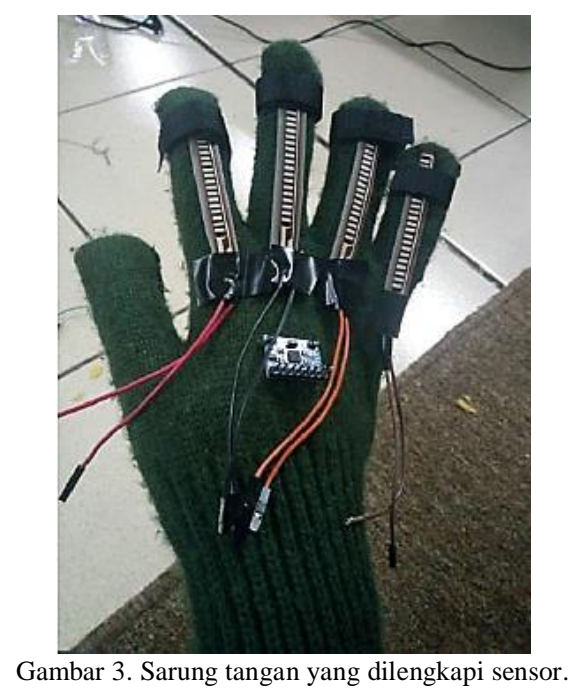

Alat bantu komunikasi penderita stroke ini juga dilengkapi dengan satu buah sensor 3-axis gyroscope. Pada penelitian ini dipilih tipe MPU6050. Alasan pemilihan komponen ini adalah karena tersedia di pasaran lokal (mudah diperoleh) dan penggunaannya yang relatif lebih mudah. MPU6050 ini merupakan sebuah Micro-Electro-Mechanical Systems (MEMS) yang terdiri dari 3-axis gyroscope dan 3-axis accelerometer. Modul sensor ini digunakan untuk menentukan posisi dan mengukur perbedaan kecepatan angular tangan. MPU6050 ini memiliki resolusi $0,01^{\circ}$, dimana spesifikasi sensor ini sudah mencukupi untuk digunakan pada alat bantu yang dikembangkan. Kelima sensor yang terpasang pada sarung tangan dapat dilihat pada Gambar 3. Berdasarkan jumlah sensor, spesifikasi ADC, dan 
adanya komputasi ringan yang digunakan untuk mengolah sinyal keluaran ADC, maka pada penelitian ini digunakan mikrokontroler berbasis Arduino dengan tipe Uno.

Pada tahap penelitian awal ini, fokus utamanya adalah penggunaan komponen dan modul elektronika yang mudah didapatkan (tersedia di pasaran lokal) untuk direalisasikan menjadi alat bantu komunikasi penderita pascastroke. Sehingga belum dilakukan adanya optimasi beberapa parameter penting, misalnya konsumsi daya dan dimensi alat.

Komunikasi gyroscope dengan Arduino dilakukan dengan menggunakan protokol InterIntegrated Circuit (I2C) yang terhubung ke pin analog Arduino. Masukan dari mikrokontroler adalah nilai tegangan digital keluaran dari ADC dan gyroscope. Nilai-nilai ini kemudian diproses oleh pengolah sinyal sederhana yang terdapat di mikrokontroler. Pengolah sinyal ini menerjemahkan nilai-nilai tersebut menjadi sebuah kata atau kalimat seperti iya, tidak, makan, minum, dll. Oleh karena itu, perlu dibuat sebuah look-up table yang berisi "kamus" nilai dari sensor dengan kata atau kalimat sederhana. Apabila nilai keluaran dari kelima sensor terdapat di look-up table, maka kata atau kalimat sederhana tersebut akan ditampilkan ke display. Apabila tidak ada, maka tampilan display akan kosong. Pada penelitian ini digunakan sebuah Personal Computer (PC) untuk menampilkan kalimat pada serial monitor, supaya kerabat atau sahabat dapat mengerti apa maksud dari gerakan tangan penderita pascastroke.

\section{PENGUJIAN DAN ANALISIS}

\subsection{Pengujian}

Pengujian dilakukan menjadi beberapa tahap. Tahap pertama adalah melakukan kalibrasi terhadap keempat flex sensor yang akan dipasang pada jari telunjuk, tengah, manis, dan kelingking. Kalibrasi juga dilakukan pada sensor gyroscope MPU6050. Tahap ini perlu dilakukan untuk menentukan gerakan dasar jari tangan. Terdapat dua gerakan dasar dariflex sensor yang digunakan, yaitu pada saat flex sensor dalam keadaan lurus (membentuk sudut $0^{\circ}$ ) dan bengkok (membentuk sudut $90^{\circ}$ ). Nilai resistensi keempat flex sensor pada kedua posisi tersebut dapat dilihat pada Tabel 1. Seperti yang telah dijelaskan sebelumnya, pada penelitian ini digunakan rangkaian pembagi tegangan untuk mengubah perubahan resistansi menjadi tegangan. Pada rangkaian pembagi tegangan, diigunakan resistor referensi sebesar $3 \mathrm{k} \Omega$, yang terhubung seri dengan flex sensor.

\begin{tabular}{|c|c|c|}
\hline $\begin{array}{c}\text { Flex Sensor } \\
\text { di Jari }\end{array}$ & 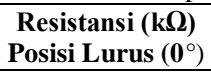 & $\begin{array}{c}\text { Resistansi (k } \Omega) \\
\text { Posisi Bengkok }\left(90^{\circ}\right)\end{array}$ \\
\hline Telunjuk & 25 & 50 \\
\hline Tengah & 25 & 61 \\
\hline Manis & 28 & 60 \\
\hline Kelingking & 43 & 73 \\
\hline
\end{tabular}

Langkah berikutnya adalah menentukan gerakan-gerakan tangan yang akan dimasukkan ke dalam look-up table. Pada penelitian ini, dibatasi hanya tujuh gerakan dasar yang diadaptasi dari ASL, yaitu kata/kalimat:

1. Ya

2. Tidak

3. Saya mau (pergi) ke sana

4. Sekarang jam berapa?

5. Halo

6. Saya mau makan

7. Saya mau minum

Tahap ketiga adalah mengambil data parameter dari kelima sensor (empat flex sensor dan satu gyroscope) yang sesuai dengan ketujuh gerakan diatas. Gambar 4 menunjukkan proses pengambilan parameter-parameter tersebut. Pada tahap ini, parameter-parameter dimunculkan ke dalam sebuah terminal di PC.

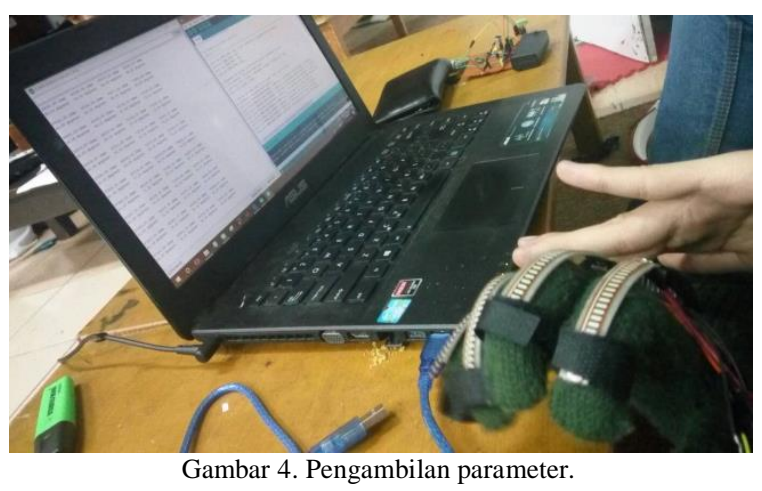

Dari ketujuh gerakan yang telah didefinisikan di atas, diperoleh beberapa parameter ukuran untuk setiap gerakan. Parameter yang diperoleh adalah empat buah resistansi (atau tegangan setelah melewati modul pembagi tegangan) serta sumbu $x, y$, dan $\mathrm{z}$ yang didapatkan dari gyroscope. Setelah melakukan percobaan sebanyak 13 kali, diperoleh parameter untuk empat buah flex sensor dan gyroscope yang digunakan untuk mendefinisikan gerakan tangan sebagai berikut:

1. Kata "Ya"

Sudut kelengkungan jari:

- Telunjuk $\geq 60^{\circ}$,

- Jari tengah $\geq 60^{\circ}$,

- Jari manis $\geq 60^{\circ}$,

- Kelingking $\geq 60^{\circ}$.

Roll: $0^{\circ}<\mathrm{x}<12^{\circ}$ dan $348^{\circ}<\mathrm{x}<360^{\circ}$,

Pitch: $0^{\circ}<\mathrm{y}<15^{\circ}$ dan $348^{\circ}<\mathrm{y}<360^{\circ}$.

2. Kata "Tidak"

Sudut kelengkungan jari:

- Telunjuk $\leq 20^{\circ}$,

- Jari tengah $\leq 20^{\circ}$,

- Jari manis $\geq 45^{\circ}$,

- Kelingking $\geq 45^{\circ}$.

Pitch: $40^{\circ}<\mathrm{y}<70^{\circ}$,

Yaw: $15^{\circ}<\mathrm{z}<350^{\circ}$. 
3. Kata "Saya mau (pergi) ke sana"

Sudut kelengkungan jari:

- Telunjuk $\leq 20^{\circ}$,

- Jari tengah $\geq 45^{\circ}$,

- Jari manis $\geq 55^{\circ}$,

- Kelingking $\geq 55^{\circ}$.

Roll: $0^{\circ}<\mathrm{x}<12^{\circ}$ dan $348^{\circ}<\mathrm{x}<360^{\circ}$,

Pitch: $0^{\circ}<\mathrm{y}<15^{\circ}$ dan $348^{\circ}<\mathrm{y}<360^{\circ}$.

4. Kata "Sekarang jam berapa?"

Sudut kelengkungan jari:

- Telunjuk $\geq 10^{\circ}$,

- Jari tengah $\geq 45^{\circ}$,

- Jari manis $\geq 35^{\circ}$,

- Kelingking $\geq 55^{\circ}$.

Roll: $0^{\circ}<\mathrm{x}<40^{\circ}$,

Pitch: $20^{\circ}<\mathrm{y}<42^{\circ}$,

Yaw: $0^{\circ}<\mathrm{z}<40^{\circ}$.

5. Kata "Halo"

Sudut kelengkungan jari :

- Telunjuk $\leq 20^{\circ}$,

- Jari tengah $\leq 20^{\circ}$,

- Jari manis $\leq 20^{\circ}$,

- Kelingking $\leq 20^{\circ}$.

Roll: $0^{\circ}<\mathrm{x}<30^{\circ}$.

Pitch: $20^{\circ}<\mathrm{y}<70^{\circ}$,

Yaw: $0^{\circ}<\mathrm{z}<40^{\circ}$.

6. Kata "Saya mau makan"

Sudut kelengkungan jari :

- Telunjuk $\geq 20^{\circ}$,

- Jari tengah $\geq 20^{\circ}$,

- Jari manis $\geq 20^{\circ}$,

- Kelingking $\geq 20^{\circ}$.

Roll: $330^{\circ}<\mathrm{x}<360^{\circ}$,

Pitch: $20^{\circ}<\mathrm{y}<60^{\circ}$,

Yaw: $330^{\circ}<\mathrm{z}<360^{\circ}$.

7. Kata "Saya mau minum"

Sudut kelengkungan jari :

- Telunjuk $\geq 25^{\circ}$,

- Jari tengah $\geq 25^{\circ}$,

- Jari manis $\geq 25^{\circ}$,

- Kelingking $\geq 25^{\circ}$.

Roll: $70^{\circ}<\mathrm{x}<110^{\circ}$,

Pitch: $68^{\circ}<\mathrm{y}<98^{\circ}$,

Yaw: $50^{\circ}<\mathrm{z}<90^{\circ}$.

Pada 3 percobaan terakhir, dengan menggunakan parameter-parameter yang telah ditentukan di atas, diperoleh kesesuaian antara gerakan isyarat tangan dengan kata atau kalimatnya. Oleh karena itu, ketujuh gerakan isyarat tangan beserta parameter-parameter ini yang akan digunakan dan disimpan ke dalam sebuah look-up table.

\subsection{Hasil dan Analisis}

Alat bantu komunikasi untuk penderita pascastroke ini mampu mendeteksi tujuh gerakan yang telah ditentukan. Hal ini dibuktikan dengan telah sesuainya gerakan tangan yang dilakukan dengan luaran kata atau kalimat yang muncul di display. Penelitian ini merupakan penelitian awal, sehingga luaran dari penelitian ini berupa sebuah working prototype. Pada penelitian ini, masih terdapat beberapa kendala dalam pengembangan alat bantu komunikasi bagi penderita pascastroke ini, yaitu:

1. Pemasangan sensor harus sesuai dengan posisi yang telah ditentukan. Hal ini berkaitan dengan sensitivitas flex sensor yang cukup tinggi, yaitu $0,01^{\circ}$. Apabila flex sensor kurang terpasang di posisi yang telah ditentukan, maka pembacaan alat menjadi kurang tepat. Untuk mengatasi hal ini, perlu dilakukan kalibrasi ulang apabila terdapat perubahan letak flex sensor.

2. Kabel yang digunakan masih cukup banyak, hal ini mengakibatkan keterbatasan gerakan tangan.

\section{KESIMPULAN DAN PENGEMBANGAN LANJUTAN}

Berdasarkan realisasi alat yang telah dilakukan, alat bantu komunikasi untuk penderita pascastroke ini telah berfungsi untuk mendeteksi tujuh gerakan dasar yang biasa digunakan dalam komunikasi sehari-hari, yaitu: "Ya", "Tidak", "Saya mau pergi kesana", "Jam berapa sekarang?", "Saya mau makan", "Saya mau minum", dan "Halo!". Ketujuh kata atau kalimat juga muncul di display. Pendeteksian ketujuh gerakan ini diperoleh dari empat flex sensor serta posisi tangan di arah 3 sumbu ( $\mathrm{x}, \mathrm{y}$, dan $\mathrm{z}$ ) dari gyroscope yang diletakkan pada sebuah sarung tangan.

Alat ini diharapkan dapat menjadi awal dalam pengembangan alat bantu komunikasi untuk penderita pascastroke yang sebenarnya hanya membutuhkan komunikasi sehari-hari yang bersifat rutin dan berulang. Pengembangan lanjutan yang akan dilakukan adalah membuat versi yang lebih ringkas, sehingga dapat lebih meningkatkan kenyamanan pengguna. Disamping itu, alat juga akan dilengkapi dengan modul text-to-speech, dengan tujuan untuk lebih memudahkan komunikasi, tanpa perlu melihat ke layar penampil.

\section{DAFTAR PUSTAKA}

DAS, A., YADAV, L., SINGHAL, M., SACHAN, R., GOYAL, H., TAPARIA, K., GULATI, R., SINGH, A., and TRIVED G., 2016. Smart glove for Sign Language communications. 2016 International Conference on Accessibility to Digital World (ICADW), pp.27-31. Guwahati.

DUTTA, A., KOBETIC, R., and TRIOLO, R., 2011. Walking after partial paralysis assisted with EMG-triggered or switch-triggered functional electrical stimulation - Two case studies. 2011 IEEE International 
134 Jurnal Teknologi Informasi dan Ilmu Komputer (JTIIK), Vol. 6, No. 2, April 2019, hlm. 129-134

Conference on Rehabilitation Robotics, pp.1-6. Zurich.

FEIGIN, V.L., NORRVING, B., MENSAH., G.A., 2017. Global Burden of Stroke. Circulation Research. 120(3), pp.439-448. Hagerstown.

MAMUN, A.A., POLASH, M.D.S.J.K., and ALAMGIR, F.M., 2017. Flex Sensor Based Hand Glove for Deaf and Mute People. International Journal of Computer Networks and Communications Security, 5(2), pp.3848. Dubai.

SATHISH, S., NITHYAKALYANI, K, VINURAJKUMAR,S.,VIJAYALAKSHMI , C., \& SIVARAMAN, J., 2016. Control of Robotic Wheel Chair using EMG Signals for Paralysed Persons. Indian Journal of Science and Technology, 9(1), pp.1-3. Chennnai. 